\title{
Retinopathy of Prematurity
}

\section{Dr Partha Haradhan Chowdhury ${ }^{1 *}$ and Brinda Haren Shah ${ }^{2}$}

${ }^{1}$ Ph.D. in Optometry (Gujarat State Government University) and Professor and Principal, Shree Satchandi Jankalyan Samiti Eye Institute - Pauri, Uttarakhand, India

${ }^{2}$ M. OPTOM, Practitioner, Ahmedabad, Gujarat, India

*Corresponding Author: Dr Partha Haradhan Chowdhury, Ph.D. in Optometry (Gujarat State Government University) and Professor and Principal, Shree Satchandi Jankalyan Samiti Eye Institute - Pauri, Uttarakhand, India.
Received: March 23, 2021

Published: April 16, 2021

(C) All rights are reserved by Dr Partha Haradhan Chowdhury and Brinda Haren Shah.

\section{Abstract}

This paper describes introduction to retinopathy of prematurity, its classification and its treatment.

Keywords: Retinopathy; Prematurity; Classification; Treatment

\section{Introduction}

Retinopathy of prematurity is a bilateral condition and it is associated with neovascularization on retina.
Healthy eye

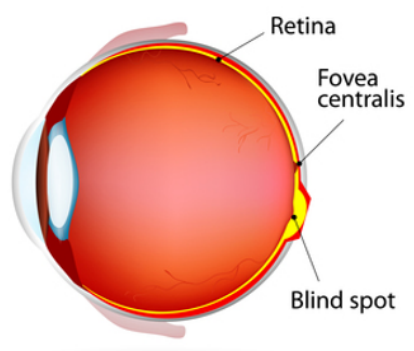

\section{Retinoblastoma}

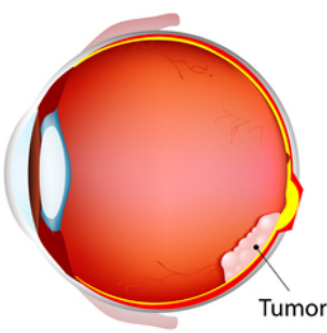

Figure 1
It is usually associated with low birth weight $(<1500 \mathrm{gm}$ of the child) and for premature baby. The earliest sign of the retinopathy of prematurity is vasodilation and tortuosity of the vessels are seen. In this case, some part of the retina becomes vascular and other parts of the retina consist of blood vessels. Here, fibrous tissue is developed and it is extended which creates a mass behind the lens, appearing as a type of pseudo retinoblastoma.

In many cases retina detaches and creates retinal detachment and patient may become blind also.

As per the fundus examination retinopathy of prematurity is considered as a stage which depends on the vascular and avascular part of the retina.

Stages: FEEST.

Stage 1

- Faint demarcation line. 


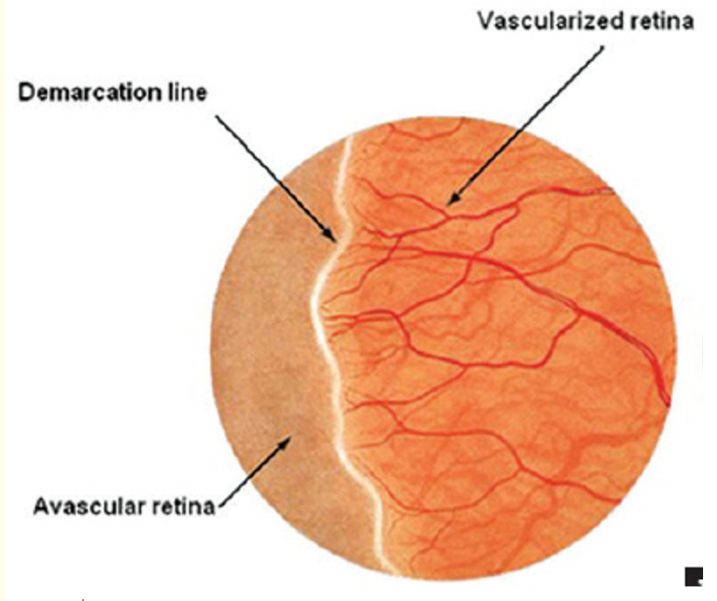

Figure 2

\section{Stage 2:}

- Elevated ridge.

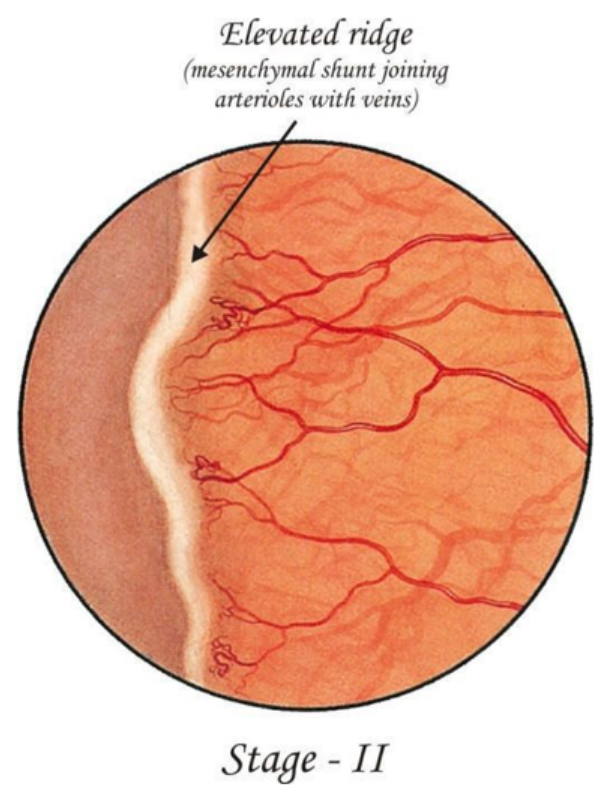

Figure 3
Stage 3:

- Extra retinal fibrovascular tissue.

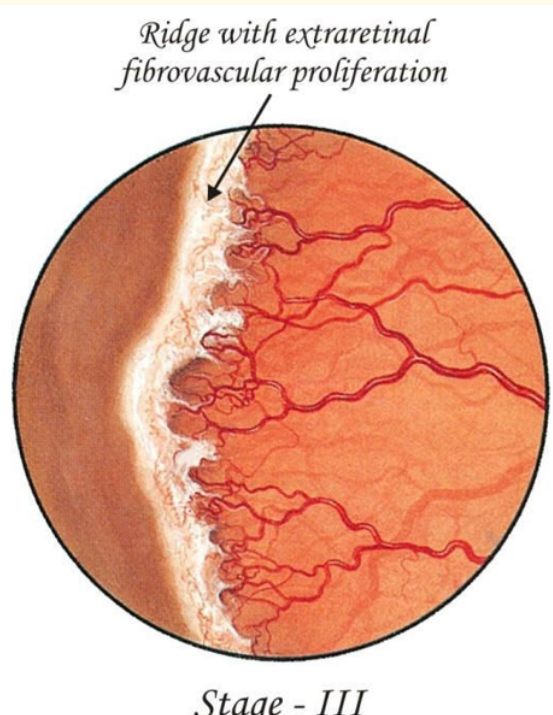

Figure 4

Stage 4:

- Sub retinal detachment.

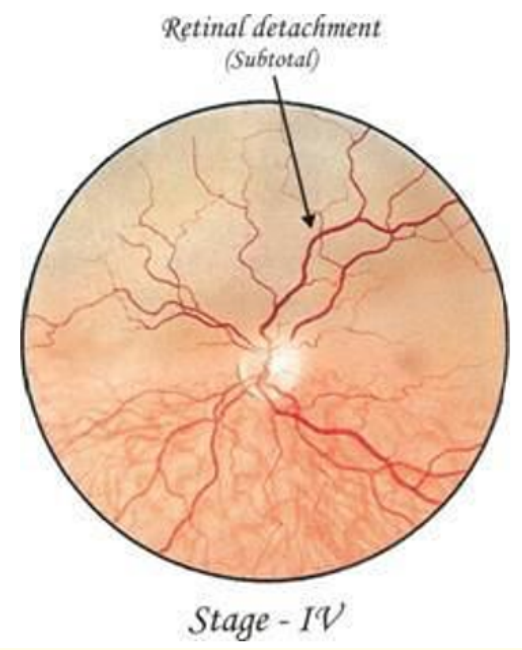

Figure 5 
Stage 5:

- Total retinal detachment.

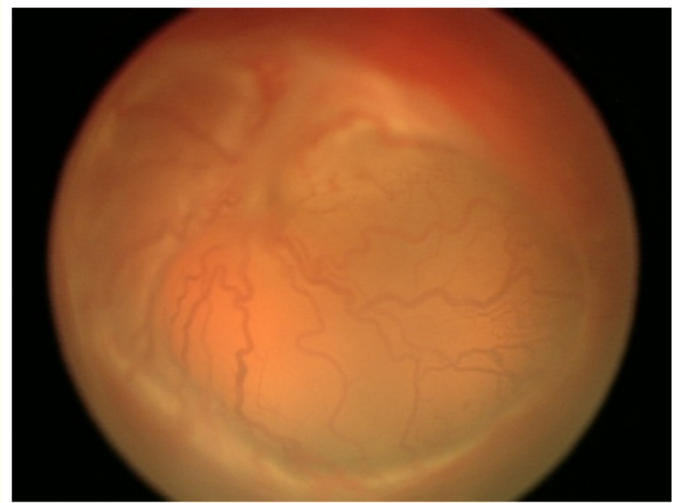

Figure 6

\section{Treatment:}

In most of the cases, surgical intervention is mandatory.

If vitreous lesion is seen then,

- Photocoagulation

- Scleral buckling

- Vit E (100 mg/kg/day).

During treatment follow up, partial pressure of oxygen level in the artery should be measured. Once retinopathy is developed, it should be reexamined every 3 to 4 months up to 4 years to check the progression of the disease [1-3].

\section{Bibliography}

1. Brad Bowling. "Kanski's Clinical Ophthalmology E-Book: A Systematic Approach". $8^{\text {th }}$ Edition (2016).

2. Sihota Radhika Tandon. "Parson's Diseases of the Eye". $22^{\text {nd }}$ Edition (2018).

3. Samar K Basak. "Clinical Ophthalmology” (2009).

\section{Assets from publication with us}

- Prompt Acknowledgement after receiving the article

- Thorough Double blinded peer review

- Rapid Publication

- Issue of Publication Certificate

- High visibility of your Published work

Website: www.actascientific.com/

Submit Article: www.actascientific.com/submission.php

Email us: editor@actascientific.com

Contact us: +919182824667 